\title{
The impact of pharmaceutical pricing and reimbursement policies on generics uptake: implementation of policy options on generics in 29 European countries-an overview
}

\author{
Sabine Vogler, $P h D$
}

\begin{abstract}
Introduction: To describe pharmaceutical pricing and reimbursement systems in 29 European countries with regard to medicines, particularly generics, and their possible impact on generics uptake.

Methods: Data collection on pharmaceutical pricing and reimbursement policies with the staff of competent authorities.

Results: In most European countries the prices of medicines are controlled at the stage of manufacture (ex-factory price) or wholesale. Usually, price control systems target reimbursable medicines, and the prices of reimbursable generics are regulated. Sixteen of the 29 countries surveyed in this study apply a policy of generic price linkage, i.e. setting the price of the generic medicines at a specific percentage lower than that of the originator. Twenty-two of the surveyed countries run a reference price system, i.e. a reimbursement policy based on clusters of identical or similar medicines for which a fixed amount of reimbursement is granted. Most countries cluster medicines with the same active ingredient, and only a few countries have opted for broader reference groups, thus allowing more interchangeability between choice of medicines and higher savings on costs. Demand-side measures such as generics substitution and/or prescribing by the international non-proprietary name are in place in nearly all the countries surveyed. These are usually not mandatory for the stakeholders concerned.

Conclusion: As many pharmaceutical policies tend to address reimbursable medicines, generics fall under the scope of these measures. European countries apply a mix of specific measures to promote generics uptake. There appears to be room for improvement regarding the enforcement of some policies.
\end{abstract}

Keywords: Generics policies, generics substitution, INN prescribing, pricing, reference price system, reimbursement

\section{Introduction}

This article aims to provide an overview about pharmaceutical pricing and reimbursement policies which European countries, including all EU Member States, apply to promote the use of generic medicines.

In the EU, Member States are free to develop their nationaland regional-pharmaceutical policies in the field of pricing and reimbursement. This is permitted so long as they comply with overall EU provisions, such as the Transparency Directive [1], e.g. formal procedural aspects such as deadlines or a transparent publication policy. Despite EU harmonisation of marketing authorisation [2], EU Member States can freely design their pharmaceutical pricing and reimbursement framework, thus opting for more market control and/or promoting competition with regard to generics and other pharmaceutical products.

All European countries are facing growing pharmaceutical expenditure, particularly in public expenditure [3] given that Europe has a comparatively higher coverage of publicly funded health care compared to the rest of the world [4]. For example, two thirds of European pharmaceutical expenditure is funded by a third party payer such as social health insurance, despite individual countries varying in the share of public funded medicines $[5,6]$. Public pharmaceutical expenditure in the outpatient sector increased in EU countries by $76 \%$ between 2000 and 2009 (median: 53\%; lowest value: 21\%; highest value: 243\%) [5, 7]. Aggravating the situation further, the global financial crisis has forced several European countries to introduce short-term rigid cost-containment measures [8].

With limited budgets, European countries view generics as a policy option that enables savings to be made and which can then be used for funding high-cost medicines. As stated in the European Commission's Communication on a Renewed Vision of the Pharmaceutical Sector: '[m]any Member States recognise that generic medicines play an important role in helping to limit their healthcare expenditure in their reimbursement and prescribing practices. Competition with off-patent products enables sustainable treatment of more patients with less financial resources. The generated savings create financial headroom for innovative medicines' [9].

Different European countries vary in the size of the pharmaceutical market occupied by generic medicines, with high shares apparent for several central and eastern European countries, Germany, The Netherlands and UK. Figure 1 also shows that

Author for correspondence: Sabine Vogler, PhD, Health Economics Department, Head of WHO Collaborating Centre for Pharmaceutical Pricing and Reimbursement Policies, Gesundheit Österreich (Austrian Health Institute)/Geschäftsbereich ÖBIG, 6 Stubenring, AT-1010 Vienna, Austria, sabine.vogler@goeg.at

Submitted: 18 April 2011; Revised manuscript received: 5 March 2012; Accepted: 9 March 2012 
some countries, while starting at a lower point, have succeeded in growing their generics markets in recent years.

This article provides: first, an up-to-date picture of the pharmaceutical pricing and reimbursement policies aimed at promoting generics uptake, and second, a discussion of the possible impact of different generics policies on the generics market.

\section{Methods}

The author and her team collected information from European countries on generics policies and further measures that have an impact on generics use. This was achieved through direct contact with representatives of the competent public authorities responsible for pharmaceutical pricing and reimbursement.

The author and her team have established good contacts with national officials in their role as coordinators of the Pharmaceutical Pricing and Reimbursement Information (PPRI) and the Pharmaceutical Health Information System (PHIS) networks, to which representatives of public authorities belong. PPRI is a networking and information-sharing initiative on pharmaceutical policies which emerged from a European Commission co-funded project under the same name $[6,10]$. As of February 2012, PPRI consisted of more than 60 institutions, mainly medicines agencies, ministries of health, and social insurance institutions, from 39 countries. These include all 27 EU Member States, nine further European countries and three non-European countries, plus European and international institutions (European Commission services and agencies, OECD, WHO and World Bank). PHIS was a similar project, broader in scope (including the hospital sector), and involving both public authority staff and hospital pharmacists [11].

These two projects produced a wealth of information which was considered when designing and drafting this article. Of particular

Figure 1: Generics market shares, in volume, in percentage of outpatient market in EU Member States

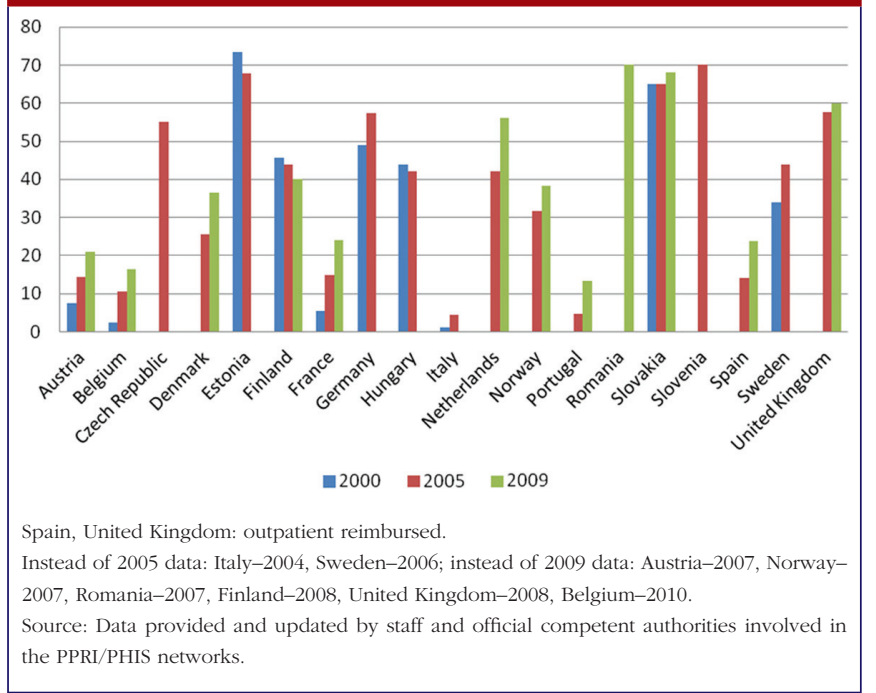

relevance were the PPRI and PHIS Pharma Profiles-national country reports about the pharmaceutical pricing and reimbursement system, written by public authority staff.

After identifying relevant information and policies, data were collected in three steps in the spring of 2011:

1. Review of country reports produced in PPRI and PHIS (published PPRI Pharma Profiles [12], PHIS Pharma Profiles [13]-available as unpublished drafts, and posters on the pharmaceutical systems [14])

2. Requests to PPRI/PHIS network members to validate the accuracy and timeliness of information, using an Intranet tool to access overview tables and figures

3. Reminders and personal communications in writing and by telephone about missing or unclear information

The article focuses on EU. It covers all 27 EU Member States plus the candidate countries Croatia and Norway-for its interesting generics policies. The manuscript was revised according to changes reported by PPRI members during 2011 and in early 2012.

\section{Results}

The pricing and reimbursement framework is an essential part of a pharmaceutical system. Pharmaceutical pricing and reimbursement policies might be individually designed for different groups of medicines such as innovative medicines, hospital medicines and/or generics.

In terms of pricing, a country may allow free pricing for (some) medicines, i.e. the manufacturer may freely decide on the price, or the authorities can regulate medicine prices according to various price setting methodologies and criteria.

In most European countries manufacturer prices (ex-factory prices) are directly regulated by the State, see Table 1 . However, in a few countries (Cyprus-for imported medicines, Denmark, Finland, Latvia, The Netherlands, Norway, Poland, Sweden and UK) the ex-factory price is indirectly regulated. For example, in Nordic countries, the relevant authorities approve a maximum wholesale price; and in the UK, the Pharmaceutical Pricing Regulation Scheme controls the maximum profits of companies.

At the manufacturer level, most countries surveyed control medicine prices only for reimbursable medicines-whose costs are at least partially covered by the national health services or social health insurance [15]. Five countries apply price regulation to all medicines, whereas Denmark and Germany are typically defined as 'free pricing countries'. However, even these countries have long-operated price controls on reimbursable off-patent products. Additionally, ongoing reform in Germany has introduced a kind of price control for new medicines [16].

In summary, a major feature of price control is reimbursement status: reimbursable medicines tend to be subject to state price control whereas non-reimbursable medicines are allowed free pricing. The same applies to reimbursable versus non-reimbursable generics. 
At the distribution stages (wholesale and pharmacy), the scope of medicines price control is broader: several countries regulate the remuneration for distributors, usually in the form of maximum linear, or regressive, markups. A few other countries only regulate the distribution markup of reimbursable medicines; including generics, see Table 1.

A common method for determining medicine prices is external price referencing-international price comparison. In 25 of the 29 countries surveyed, competent authorities check medicines prices in other countries when setting and/or negotiating a price. Only Denmark, Sweden and UK do not apply external price referencing, while Germany is just beginning to consider medicine prices elsewhere with regard to certain new medicines [7, 12, 13, 16, 17].

External price referencing is typically limited, however, to original products [17]. The most common pricing procedure applied to generic medicines is internal price referencing. This is the practice of using the price(s) of identical or similar products in a country when setting a price.

Sixteen countries surveyed required generics-and other 'follower products'-to be priced at a certain percentage lower than the originators-a policy called 'generic price linkage' [3], see Table 2. Austria and Estonia, for example, specify that not only the first 'follower', but also all additional followers and the original products are required to lower their price. Since 2005, Norway has used the 'stepped price model' (Trinnprismodellen) to incrementally reduce the price of a medicine according to predefined rates, depending on sales volumes.

\begin{tabular}{|c|c|c|c|}
\hline Price control & $\begin{array}{l}\text { At manufacturer } \\
\text { level }\end{array}$ & For wholesalers & $\begin{array}{l}\text { For } \\
\text { pharmacists }\end{array}$ \\
\hline For all medicines & $\mathrm{BE}, \mathrm{CZ}, \mathrm{EL}, \mathrm{LU}, \mathrm{LV}^{1}$ & $\begin{array}{l}\mathrm{AT}^{2}, \mathrm{BE}, \mathrm{CZ}, \mathrm{EE}, \\
\mathrm{EL}, \mathrm{ES}, \mathrm{HR}, \mathrm{HU} \\
\mathrm{LU}, \mathrm{PT}, \mathrm{SI}^{3}\end{array}$ & $\begin{array}{l}\mathrm{AT}^{4}, \mathrm{BE}, \mathrm{CY}^{5}, \\
\mathrm{CZ}, \mathrm{DK}^{6}, \mathrm{EE}, \\
\mathrm{EL}, \mathrm{ES}, \mathrm{FI}^{7}, \mathrm{HR}, \\
\mathrm{HU}, \mathrm{LU}, \mathrm{LV}, \\
\mathrm{NO}, \mathrm{PT}, \mathrm{SI}^{3}\end{array}$ \\
\hline $\begin{array}{l}\text { For reimbursable } \\
\text { medicines* }\end{array}$ & $\begin{array}{l}\text { AT, } \mathrm{DE}^{8}, \mathrm{DK}^{1,8}, \mathrm{EE}, \\
\mathrm{ES}, \mathrm{FI}^{1}, \mathrm{FR}, \mathrm{HU}, \\
\mathrm{HR}, \mathrm{IE}, \mathrm{IT}, \mathrm{LT}, \mathrm{PL}^{1}, \\
\mathrm{SE}^{1}, \mathrm{SI}, \mathrm{SK}, \mathrm{UK}^{9}\end{array}$ & $\begin{array}{l}\mathrm{DE}^{10}, \mathrm{FR}, \mathrm{IE}^{11}, \\
\mathrm{IT}, \mathrm{LT}, \mathrm{PL}, \mathrm{SK}, \\
\mathrm{UK}\end{array}$ & $\begin{array}{l}\mathrm{DE}^{10}, \mathrm{FR}, \mathrm{IE}^{11} \\
\text { IT, LT, PL, SK, } \\
\text { UK }\end{array}$ \\
\hline $\begin{array}{l}\text { For prescription } \\
\text { only medicines }\end{array}$ & $\begin{array}{l}\mathrm{BG}, \mathrm{NL}^{1}, \mathrm{NO}^{1}, \mathrm{PT}, \\
\mathrm{RO}\end{array}$ & $\mathrm{BG}, \mathrm{RO}$ & $\begin{array}{l}\text { BG, NL, RO, } \\
\text { SE }\end{array}$ \\
\hline Others & $\mathrm{CY}^{12}, \mathrm{MT}^{13}$ & $\mathrm{CY}, \mathrm{MT}^{5}$ & $\mathrm{MT}^{5}$ \\
\hline \multicolumn{4}{|c|}{$\begin{array}{l}\text { "Eligible for reimbursement, costs are partially or fully funded covered by the state; 'price is regulated at } \\
\text { wholesale level instead of manufacturer price level; no statutory wholesale markups are in place; }{ }^{2} \text { two } \\
\text { different wholesale markup schemes depending on the reimbursement category of the medicine; }{ }^{3} \text { except } \\
\text { non-reimbursable over-the-counter medicines; }{ }^{4} \text { two different pharmacy markup schemes for different kind } \\
\text { of customers; }{ }^{5} \text { private sector only; }{ }^{6} \text { except over-the-counter medicines sold outside the pharmacy; }{ }^{7} \text { except } \\
\text { nicotine replacement therapy sold outside the pharmacy; }{ }^{8} \text { reimbursable off-patent products; }{ }^{\text {indirect }} \\
\text { price control through Pharmaceutical Pricing Regulation Scheme; }{ }^{10} \text { two different schemes for prescription- } \\
\text { only medicines and for reimbursable over-the-counter medicines; }{ }^{11} \text { for different reimbursement schemes; } \\
{ }^{12} \text { at wholesale level for imported medicines (private sector); }{ }^{13} \text { pubblic sector only. } \\
\text { AT: Austria; BE: Belgium; BG: Bulgaria; CY: Cyprus; CZ: Czech Republic; DE: Germany; DK: Denmark; } \\
\text { EE: Estonia; EL: Greece; ES: Spain; FI: Finland; FR: France; HR: Croatia; HU: Hungary; IE: Ireland; } \\
\text { IT: Italy; LT: Lithuania; LU: Luxembourg; LV: Latvia; MT: Malta; NL: Netherlands; NO: Norway; PL: Poland; } \\
\text { PT: Portugal; RO: Romania; SE: Sweden; SI: Slovenia; SK: Slovakia; UK: United Kingdom. } \\
\text { Source: Data provided and updated by staff and official competent authorities involved in the PPRI/PHIS } \\
\text { networks. }\end{array}$} \\
\hline
\end{tabular}

The first reduction occurs after a medicine has lost patent protection [21, 22].

Key elements of pharmaceutical reimbursement systems are reference price systems and reimbursement listspositive lists for medicines eligible for reimbursement and negative lists specifying products explicitly excluded from reimbursement [15].

Positive lists are in place in 26 of the surveyed countries (all but Germany, Spain, UK), whereas negative lists are only used in Germany, Hungary, Spain, and UK. Thirdparty payers do not automatically cover the full costs of medicines from the positive lists. Full reimbursement of eligible medicines only occurs in seven countriesAustria, Germany, Ireland, Italy, Malta, The Netherlands, and UK, while elsewhere reimbursement for several medicines is at a lower rate. Criteria for inclusion on a positive list include cost-effectiveness, medical need and therapeutic value-in particular, the relative effectiveness

\begin{tabular}{|c|c|}
\hline Generic price linkage & Country \\
\hline Specific policies & $\mathrm{AT}^{1}, \mathrm{EE}^{2}, \mathrm{ES}^{3}, \mathrm{LT}^{4}, \mathrm{NO}^{5}$ \\
\hline $\begin{array}{l}\text { Generics priced below } \\
\text { originator up to (at least) 20\% }\end{array}$ & CZ, EL, IE, IT, LU \\
\hline $\begin{array}{l}\text { Generics priced at least } \\
20-50 \% \text { lower than originator }\end{array}$ & $\mathrm{BE}, \mathrm{CY}^{6}, \mathrm{HU}, \mathrm{PL}, \mathrm{PT}$ \\
\hline $\begin{array}{l}\text { Generics priced at least } 50 \% \\
\text { lower than originator }\end{array}$ & FR \\
\hline $\begin{array}{l}\text { No generic price linkage } \\
\text { to originator price required }\end{array}$ & $\begin{array}{l}\text { BG, DE, DK, } \mathrm{FI}^{7}, \mathrm{HR}^{8} \text {, } \\
\mathrm{LV}, \mathrm{MT}, \mathrm{NL}, \mathrm{RO}, \mathrm{SE}^{9}, \\
\text { SI, SK, UK }\end{array}$ \\
\hline
\end{tabular}

${ }^{1}$ The first follower is required to be priced at least $48 \%$ below the originator. The second follower needs to reduce its price by at least $15 \%$ from the price from the first follower and the originator by at least $30 \%$ within three months after the inclusion of the first follower into reimbursement. The third follower needs to reduce its price by at least $10 \%$ from the price from the second follower. At this time all of the products have to reach the price level of the third follower within three months after the inclusion of the third follower. ${ }^{2}$ The first follower is required to be priced $30 \%$ below the originator. The second follower needs to reduce its price by at least $10 \%$ and the next two followers are $5 \%$ lower. ${ }^{3}$ The follower needs to be priced below the reference price. ${ }^{4} \mathrm{New}$ regulation since January 2010: the first follower is required to be priced 30\% below the originator. The second and third follower need to reduce their price by at least $10 \%$ each. ${ }^{5}$ Stepped price model (Trinnprismodellen), see explanation in the text. ${ }^{6}$ For locally produced medicines. ${ }^{7}$ In case of the first follower priced $40 \%$ lower than the originator, a faster procedure is offered. ${ }^{8}$ Generics to be included into reimbursement are required to be priced at least 30\% lower than average price in the reference countries and at least $10 \%$ lower than the last bioequivalent generics introduced to the list. 'A price, which is lower or the same as the highest price within a group of substitutable medicines, is accepted without further investigation.

AT: Austria; BE: Belgium; BG: Bulgaria; CY: Cyprus; CZ: Czech Republic; DE: Germany; DK: Denmark; EE: Estonia; EL: Greece; ES: Spain; FI: Finland; FR: France; HR: Croatia; HU: Hungary; IE: Ireland; IT: Italy; LT: Lithuania; LU: Luxembourg; LV: Latvia; MT: Malta; NL: Netherlands; NO: Norway; PL: Poland; PT: Portugal; RO: Romania; SE: Sweden; SI: Slovenia; SK: Slovakia; UK: United Kingdom.

Source: Data provided and updated by staff and official competent authorities involved in the PPRI/PHIS networks, based on references [6, 18-20]. 
Figure 2: Reference price systems in the EU Member States, Croatia and Norway

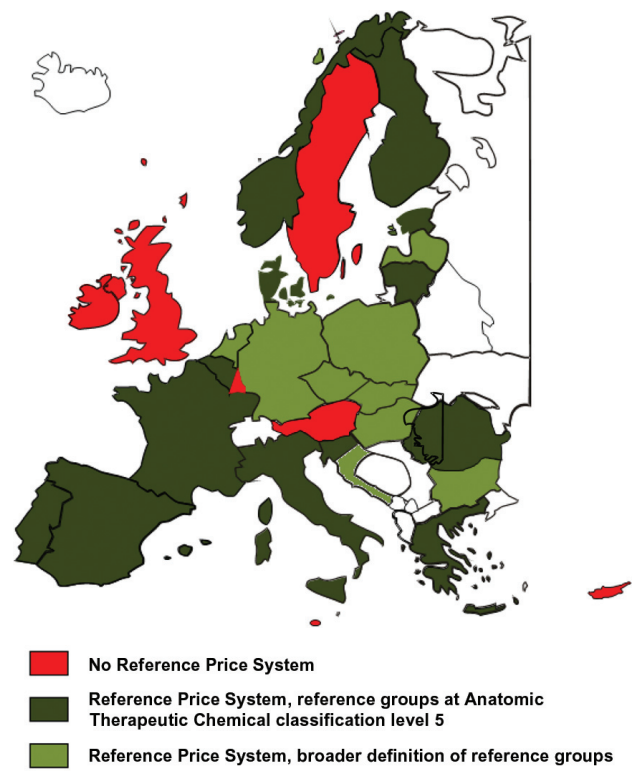

Source: Data provided and updated by staff and official competent authorities involved in the PPRI/PHIS networks.

in the case of medicines with no new, but added therapeutic value. Another consideration is the estimated budget impact-in central and eastern European countries [7].

A reference price system is a major policy option for the promotion of generics uptake. This entails clustering identical or similar products into so-called reference groups. Each cluster has a maximum reimbursement amount (reference price) to be covered by the third-party payer. The patient must pay the difference between this reference price and the actual pharmacy retail price, in addition to any other co-payments [15]. Twenty-two

Table 3: Implementation of generics substitution and prescribing by international non-proprietary name in the 27 EU Member States, Croatia and Norway

\begin{tabular}{|l|l|l|}
\hline $\begin{array}{l}\text { Status of } \\
\text { implementation }\end{array}$ & Generics substitution & $\begin{array}{l}\text { International non-proprietary } \\
\text { name prescribing }\end{array}$ \\
\hline Not allowed & $\begin{array}{l}\mathrm{AT}, \mathrm{BE}, \mathrm{BG}^{1}, \mathrm{CY}^{2}, \mathrm{EL}, \mathrm{IE}, \mathrm{LU}, \\
\mathrm{UK}^{3}\end{array}$ & $\mathrm{AT}, \mathrm{CY} \mathrm{C}^{2}, \mathrm{DK}, \mathrm{EL}, \mathrm{SE}$ \\
\hline $\begin{array}{l}\text { Implemented, } \\
\text { indicative }\end{array}$ & $\begin{array}{l}\mathrm{CZ}, \mathrm{EE}, \mathrm{FR}, \mathrm{HR}, \mathrm{HU}, \mathrm{IT}, \mathrm{LT}, \\
\mathrm{LV}, \mathrm{NL}, \mathrm{NO}, \mathrm{PT}, \mathrm{PL}, \mathrm{RO}, \mathrm{SI}, \mathrm{SK}\end{array}$ & $\begin{array}{l}\mathrm{BE}, \mathrm{BG}, \mathrm{CZ}, \mathrm{DE}, \mathrm{ES}, \mathrm{FI}, \mathrm{FR}, \\
\mathrm{NL}, \mathrm{HU}, \mathrm{IE}, \mathrm{IT}, \mathrm{LU}, \mathrm{LV}, \mathrm{MT},\end{array}$ \\
\hline $\begin{array}{l}\text { Implemented, } \\
\text { mandatory }\end{array}$ & $\mathrm{DE}, \mathrm{DK}, \mathrm{ES}, \mathrm{FI}, \mathrm{MT}^{4}, \mathrm{SE}$ & $\mathrm{EE}, \mathrm{LT}, \mathrm{PT}, \mathrm{RO}, \mathrm{SK}{ }^{5}$ \\
\hline
\end{tabular}

${ }^{1}$ plan to introduce generics substitution in 2012; ' ${ }^{2}$ ot allowed in the private sector, allowed in the public sector; introduction of generics substitution was planned for 2010, but decided not to implement this measure; ${ }^{4}$ in the public sector; ${ }^{5}$ mandatory since December 2011, before it was indicative.

AT: Austria; BE: Belgium; BG: Bulgaria; CY: Cyprus; CZ: Czech Republic; DE: Germany; DK: Denmark; EE: Estonia; EL Greece; ES: Spain; FI: Finland; FR: France; HR: Croatia; HU: Hungary; IE: Ireland; IT: Italy; LT: Lithuania; LU: Luxembourg; LV: Latvia; MT: Malta; NL: Netherlands; NO: Norway; PL: Poland; PT: Portugal; RO: Romania; SE: Sweden; SI: Slovenia; SK: Slovakia; UK: United Kingdom.

Source: Data provided and updated by staff and official competent authorities involved in the PPRI/PHIS networks. of the countries surveyed have a reference price system, 13 of which specify clusters containing medicines with the same active ingredient, see Figure 2. Most countries define the reference prices around or below the average price of generics, or at the

In addition to these pricing and reimbursement policies, European countries also employ specific demand-side measures to promote the use of generics, targeting prescribers, pharmacists and the public. For example, 23 countries surveyed use generics substitution (mandatory in six countries); while 24 countries use interin five countries), see Table 3. Public information campaigns often focus on generics with the goal of raising awareness and

\section{Discussion}

survey of generics policies and pharmaceutical pricing and a strong linkage between pricing and reimbursement, and that some policies are only relevant for reimbursable medicines. As a only those generics that are eligible for reimbursement are non-reimbursable generics do not fall within the scope of price trol. In addition, generics are specifically targeted by policies aimed at enhancing their use and saving money-for public payers.

The potential for cost-containment can be seen in the prices of generics which may be set at a lower level (generic price linkage), and via competition from the arrival of new generics on the market. The latter also leads to lower prices of other generics and othator. Both strategies, partially in parallel, occur in the countries surveyed, and add to a growing body of reports about Policymakers tend to take a broad view of generics. Several countries promote the use of not just generics but also 'nonexpensive' products. These may include copyproducts, parallel imported medicines, for example, in Denmark or Germany [18], and even less expensive original products (as in Belgium [26]). Countries vary as to the necessary price difference between a generic medicine, or other follower products, and the originator. Questions may arise over whether higher price differences are possible, and by how much, and whether lower prices might be achieved for generics through policies other than the generic price linkage. Countries, which do not explicitly require generics to be priced at a certain percentage lower still report considerable price differences, for example, The Netherlands $[18,28]$ and Slovakia [27]. This they attribute to market competition, for instance, supported by tendering mechanisms in the outpatient sector [29]. In addition, according to a literature review, while generic price linkages and price regulation did succeed in lowering generic medicine prices to a certain point, there were 


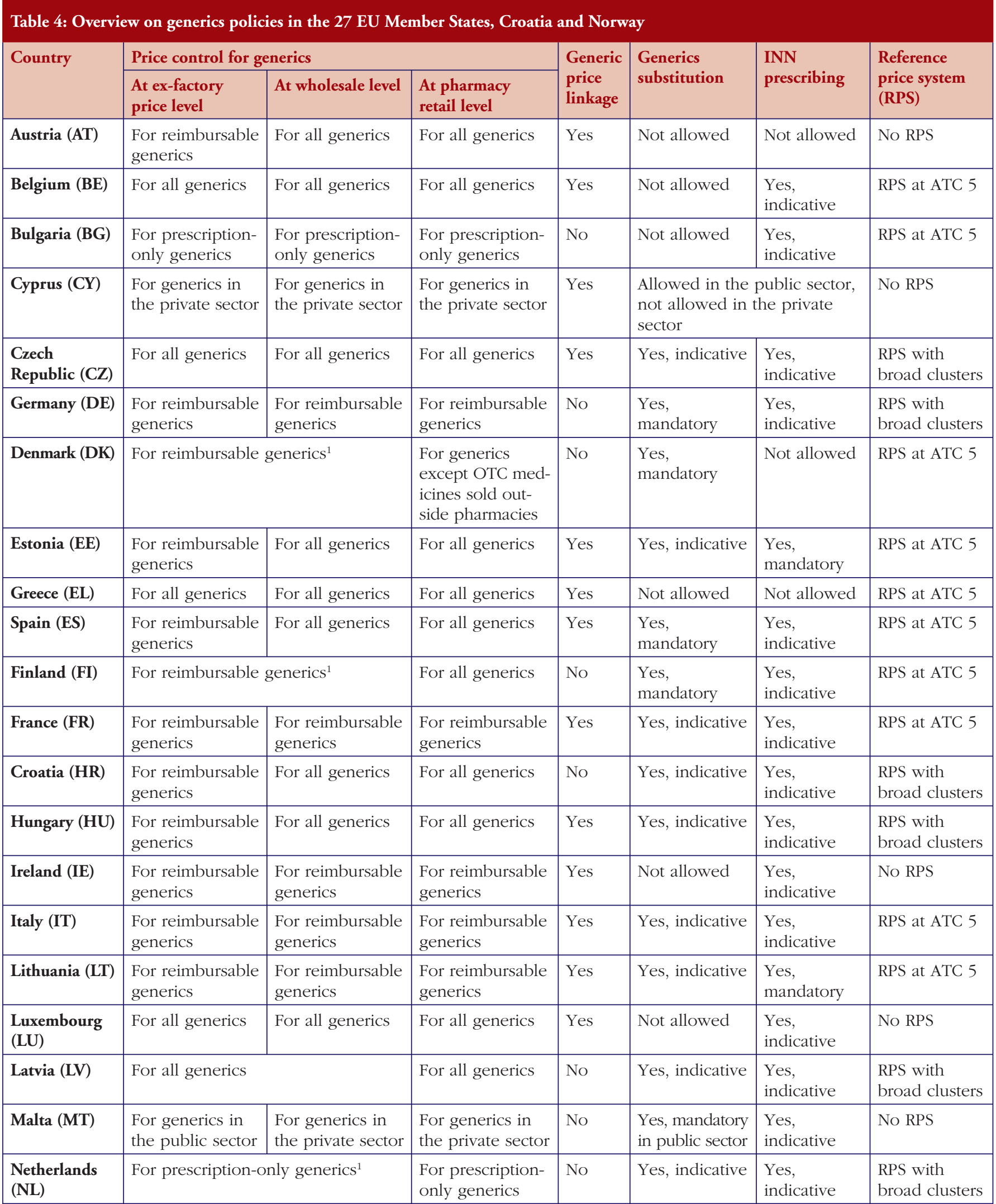




\begin{tabular}{|c|c|c|c|c|c|c|c|}
\hline Country & $\begin{array}{l}\text { At ex-factory } \\
\text { price level }\end{array}$ & At wholesale level & $\begin{array}{l}\text { At pharmacy } \\
\text { retail level }\end{array}$ & $\begin{array}{l}\text { Generic } \\
\text { price } \\
\text { linkage }\end{array}$ & $\begin{array}{l}\text { Generics } \\
\text { substitution }\end{array}$ & $\begin{array}{l}\text { INN } \\
\text { prescribing }\end{array}$ & $\begin{array}{l}\text { Reference } \\
\text { price system } \\
\text { (RPS) }\end{array}$ \\
\hline Norway (NO) & \multicolumn{2}{|c|}{ For prescription-only generics ${ }^{1}$} & For all generics & Yes & Yes, indicative & $\begin{array}{l}\text { Yes, } \\
\text { indicative }\end{array}$ & RPS at ATC 5 \\
\hline Portugal (PT) & $\begin{array}{l}\text { For prescription- } \\
\text { only generics }\end{array}$ & For all generics & For all generics & Yes & Yes, indicative & $\begin{array}{l}\text { Yes, } \\
\text { mandatory }\end{array}$ & RPS at ATC 5 \\
\hline Romania (RO) & $\begin{array}{l}\text { For prescription- } \\
\text { only generics }\end{array}$ & $\begin{array}{l}\text { For prescription- } \\
\text { only generics }\end{array}$ & $\begin{array}{l}\text { For prescription- } \\
\text { only generics }\end{array}$ & No & Yes, indicative & $\begin{array}{l}\text { Yes, } \\
\text { mandatory }\end{array}$ & $\begin{array}{l}\text { RPS with } \\
\text { broad clusters }\end{array}$ \\
\hline Slovakia (SK) & $\begin{array}{l}\text { For reimbursable } \\
\text { generics }\end{array}$ & $\begin{array}{l}\text { For reimbursable } \\
\text { generics }\end{array}$ & $\begin{array}{l}\text { For reimbursable } \\
\text { generics }\end{array}$ & No & Yes, indicative & $\begin{array}{l}\text { Yes, } \\
\text { mandatory }\end{array}$ & $\begin{array}{l}\text { RPS with } \\
\text { broad clusters }\end{array}$ \\
\hline $\begin{array}{l}\text { United } \\
\text { Kingdom } \\
\text { (UK) }\end{array}$ & $\begin{array}{l}\text { Indirect price } \\
\text { control for } \\
\text { reimbursable } \\
\text { generics }\end{array}$ & $\begin{array}{l}\text { For reimbursable } \\
\text { generics }\end{array}$ & $\begin{array}{l}\text { For reimbursable } \\
\text { generics }\end{array}$ & No & Not allowed & $\begin{array}{l}\text { Yes, } \\
\text { indicative }\end{array}$ & No RPS \\
\hline
\end{tabular}

${ }^{1}$ price is regulated at wholesale level instead of manufacturer price level; no statutory wholesale markups are in place; ATC: Anatomic Therapeutic Chemical classification system by WHO; ATC 5: defines a single active ingredient or a fixed combination of active ingredients within the ATC classification system, i.e. RPS is based on the same active ingredients; INN: international nonproprietary name; OTC: over-the-counter.

Source: Data provided and updated by staff and official competent authorities involved in the PPRI/PHIS networks.

indications for a higher potential for savings which might be triggered by free-price competition in the generics market [30].

A widely-used approach to promote generics in European countries is the introduction of demand-side measures, notably generics substitution and INN prescribing. Ten countries in the survey combined these two measures. A few countries have either one or other in place (six countries with INN prescribing but no generics substitution, three countries with generics substitution but no INN prescribing, see Tables 3 and 4. The choice of just one of the policies could be due to its appearing sufficient for achieving the expected results. In the UK, with a high rate of INN prescribing and a comparatively high generics market share, the government decided against the introduction of generics substitution planned for 2010 following a public consultation [31]).

A common combination, however, is generics substitution or INN prescribing together with a reference price system-seen in 20 countries. In combination, these two tools appear to positively influence each other [6]. Among the countries surveyed, only one country (Austria) lacks all three of the aforementioned policies. Its generics market shares are comparably low, but are now on the increase following the introduction of a generics price linkage policy [32].
It is important to highlight not only the quantity of measures, but also the quality of their implementation. Stringent implementation of a few measures can produce the desired effects. For instance, Sweden produced a high generics market share even after abolishing the reference price system, perhaps because another system of clustering similar medicines already existed, as well as mandatory generics substitution [6, 33, 34] and discussion/references below. Norway's stepped price model, introduced in 2005, has increased the market share for generics from $31.8 \%$ of the volume of the outpatient market in 2005 to $38.4 \%$ in 2007 , see Figure 1. Norway has thus 'ensured that prices for generics have fallen' [22]. But in the context of Norway's overall pricing policies, the introduction of a pricing regime linked to prices in other European countries, and the design of their external price referencing, had a moderating effect on the Norwegian price level in general $[35,36]$.

The level of enforcement also affects the success of new measures to promote generics use and control prices [6, 18]. Policy measures, such as generics substitution and/or INN prescribing, might be implemented on a voluntary or a mandatory basis. A voluntary implementation occurs in the majority of countries surveyed, but some, for example, Lithuania and Slovakia, have changed their legislation and made INN prescribing obligatory. 
This mandatory implementation of a policy has proved successful at increasing generics uptake, for example, in Sweden [6, 37, 38].

Besides mandatory enforcement (possibly accompanied by financial sanctions), incentives for stakeholders can also be an issue. In The Netherlands, a financial incentive was in place for years allowing pharmacists to retain one third of the difference between the price of the medicine and the reference price if they dispensed a medicine below the reference price [39]. This incentive appears to have contributed to an increase in the generics market share, but interestingly, after the abolition of the measure in 2005, the generics substitution rate continued to stay at a high level and even rose ( $42 \%$ in volume of total market in 2005, 56\% in 2009, see Figure 1). Some experts feel that the continuing high substitution rate is attributable to a positive attitude that has developed among Dutch pharmacists [18]. Another example is a pilot project in Austria, in which patients of a small sickness fund were charged a lower prescription fee if they obtained a generic instead of a brand-name medication. As a result, the patients asked for the generics and the share of generics prescriptions rose [40].

These examples suggest that in addition to formal mechanisms, such as punishing sanctions or encouraging incentives, a 'generics culture', i.e. a positive attitude and trust in generics (and biosimilars), may contribute significantly to an increased use of generics. We recommend the development of such a culture, using strategies that target all stakeholders, including patients.

Finally, the organisation of a reference price system is another trigger for generics uptake. Twenty-two of the European countries surveyed have a reference price system; thirteen of these organise the reference groups at the Anatomic Therapeutic Chemical classification level 5, in other words, clustering of medicines with the same active ingredient, see Figure 2. This is the easiest way to manage the system and probably an appropriate starting point when introducing such a policy. However, care should be taken over the definition of a cluster: a very narrow cluster can result in some patients re-allocating their demand away from the reference group to an alternative non-patent medicine, with the consequent loss of potential savings [18, 23, 39, 41]. Such 're-allocation of demand' has been observed, to some extent, in a few European countries, for example, France and Italy [42].

Another relevant parameter in the design of a reference price system is the fixed reimbursement amount, i.e. the so-called reference price. In mature high-volume generics markets such as in Poland, a higher reimbursement amount might be advisable for a brief period, to provide incentives for generics manufacturers to enter the market [43]. A lower reference price generally results in higher savings. In this respect, Portugal, which initially set the reference price at that of the highest priced generics in the reference group [44, 45], decided in 2010 to reset the price to the average of the five lowest priced medicines [8]. In future it will be useful to examine the impact of this decision on the generics market shares. Further, in five other European countries: Belgium, Estonia, Latvia, Lithuania, Spain; the methodology regarding the calculation of the reference price was changed in 2010 and 2011 [8], apparently for cost-containment reasons, because these countries were strongly hit by the global financial crisis.

\section{Conclusion}

European pharmaceutical systems use several different types of pricing and reimbursement policies for medicines including reimbursable medicines. Generics, if deemed reimbursable, are subject to the same policies. In addition, many countries have implemented specific measures to promote generics uptake, including demand-side measures targeting prescribers, pharmacists and, less frequently, patients. Usually, a mix of policies is employed. The design of these measures can significantly influence generics uptake and the degree of public savings. However, the difficulties in enforcing these measures should be addressed. Creating a 'generics culture', i.e. an environment which is positive towards generics, appears to support other policy measures.

\section{For patients}

Several European countries aim to increase generics uptake, this allows offering medicines at lower prices for the sake of patients who have to pay out-of-pocket and/or to co-pay. In the case of publicly funded medicines it also offers savings for the healthcare system and thus provides financial headroom for funding innovation, therefore, increasing both accessibility and affordability to patients. Evidence about generics policies helps not only the policymakers to reach their aims but also the patients benefiting from improved accessibility and affordability.

\section{Acknowledgements}

The author wishes to express sincere appreciation to the participants of the PPRI/PHIS network members who, by writing country reports and responding to requests for validating the accuracy and timeliness of data, helped to provide information about major pharmaceutical pricing and reimbursement policies. Particular thanks go to the PPRI/PHIS team members at Gesundheit Österreich, Ms Christine Leopold and Ms Nina Zimmermann, for their support in surveying and monitoring the information, and Mr Borja Garcia-Lorenzo, intern at Gesundheit Österreich, for his assistance with the figures used in this article.

\section{Competing interests: None.}

Provenance and peer review: Commissioned; externally peer reviewed.

\section{References}

1. Council Directive $89 / 105 /$ EEC of 21 December 1988 relating to the transparency of measures regulating the prices of medicinal products for human use and their inclusion in the scope of national health insurance systems. [cited 2012 May 22]. Available from: eurlex.europa.eu/LexUriServ/LexUriServ. do?uri=CELEX:31989 L0105:en:HTML

2. Pignatti $\mathrm{F}$, et al. Overview of the European regulatory approval system. J Ambul Care Manage. 2004;27:89-97.

3. OECD [homepage on the Internet]. Pharmaceutical pricing policies in a global market. Paris: OECD Health Policy Studies; 2008. Available from: www.oecd. org/document/36/0,3746,en_2649_33929_41000996_1_1_1_1,00.html

4. World Health Organization. The world medicines situation. Geneva: World Health Organization; 2004.

5. OECD [homepage on the Internet]. Health Database 2010. Available from: www.oecd.org/document

6. Vogler S, Habl C, Leopold C, Rosian-Schikuta I, de Joncheere K, Lyager Thompsen T. PPRI Report. Vienna: Gesundheit Österreich GmbH/Geschäftsbereich ÖBIG; 2008. 
7. Vogler S, Habl C, Bogut M, Voncina L. Comparing pharmaceutical pricing and reimbursement policies in Croatia to the European Union Member States Croat Med J. 2011;52(2):183-97.

8. Vogler S, Zimmermann N, Leopold C, de Joncheere K. Pharmaceutical policies in European countries in response to the global financial crisis. Southern Med Review. 2011;4(2):22-32.

9. Commission Communication of 10 December 2008 COM (2008) 666: final Safe, innovative and accessible medicines: a renewed vision for the pharmaceutical sector. DG Competition of the European Commission. Pharmaceutical Sector Inquiry. Brussels, July 2009. Available from: eur-lex.europa.eu/ LexUriServ/LexUriServ.do?uri=COM:2008:0666:FIN:en:PDF

10. Arts D, et al. Pharmaceutical Pricing and Reimbursement Information (PPRI): a European Union project. Italian Journal of Public Health. 2006;3(1): 36-40.

11. Mantel-Teeuwisse A, Hoebert J. PHIS evaluation report. Utrecht: Utrecht University/WHO Collaborating Centre for Pharmacoepidemiology and Pharmaceutical Policy Analysis, Winter 2011.

12. PPRI Pharma Profiles. 2006/2007/2008 [cited 2012 May 22]. Available from: ppri.goeg.at and whocc.goeg.at

13. PHIS Pharma Profiles. 2010/2011 [cited 2012 May 22]. Available from: whocc goeg.at

14. Posters about pharmaceutical system. [cited 2012 May 22]. Available from: whocc.goeg.at

15. PHIS/AIFA/GÖG. PHIS Glossary: Glossary for pharmaceutical policies/ systems developed in the Pharmaceutical Health Information System (PHIS) Project. July 2009 [update 2012 Apr; cited 2012 May 22]. Available from: phis. goeg.at/index.aspx?_nav0020

16. Ognyanova D, et al. Pharmaceutical reform 2010 in Germany. Eurohealth. 2011;17(1):11-3.

17. Leopold C, Vogler S, Mantel-Teeuwisse AK, de Joncheere K, Leufkens HGM Laing R. Differences in external price referencing in Europe-a descriptive overview. Health Policy. 2012:104(1):50-60.

18. Habl C, Vogler S, Leopold C, Schmickl B, Fröschl B. Reference price systems in Europe. Analysis and prerequisites for an implementation in Austria [in German]. Vienna: ÖBIG Forschungs-und Planungsgesellschaft mbH; 2008.

19. Godman B, Shrank W, Wettermark B, Andersen M, Bishop J, Burkhardt T. Use of generics-a critical cost containment measure for all healthcare professionals in Europe? Pharmaceuticals. 2010;3:2470-94.

20. Voncina L, Strizrep T. Croatia: 2009/2010 pharmaceutical pricing and reimbursement reform. Eurohealth. 2011;16(4):20-2.

21. Festöy H, Sveen K, Leung-Ming Y, Gjönnes L, Gregersen T. PPRI pharma profile Norway. Oslo: PPRI; 2008 [cited 2012 May 22]. Available from: ppri.goeg.at

22. Torfinn A, Festøy H, Yu LM, Ognøy A, Gregersen T. PHIS pharma profile Norway. Oslo: PHIS; 2011 [cited 2012 May 22]. Available from: whocc.goeg.at

23. Espin J, Rovira J. Analysis of differences and commonalities in pricing and reimbursement systems in Europe. Brussels: DG Enterprise and Industry of the European Commission; 2007.

24. Vogler S, Schmickl B. Rational use of medicines [in German, executive summary report available in English]. Vienna: Gesundheit Österreich GmbH/ Geschäftsbereich ÖBIG; 2010.

25. Godman B, et al. European payer initiatives to reduce prescribing costs through use of generics. Generics and Biosimilars Initiative Journal (GaBI Journal). 2012;1(1):22-7. doi: 10.5639/gabij.2012.0101.007
26. DeSwaef A, Antonissen Y. PPRI Pharma Profile Belgium. Brussels: PPRI; 2008 [cited 2012 May 22]. Available from: ppri.goeg.at

27. Mazag J, Segeč A. PPRI Pharma Profile Slovakia. Bratislava: PPRI; 2007 [cited 2012 May 22]. Available from: ppri.goeg.at

28. Zuidberg C, Vogler S, Mantel-Teeuwisse A. The pharmaceutical system of the Netherlands: a comparative analysis between the Dutch out-patient pharmaceutical system, in particular the pricing and reimbursement characteristics, and those of the other European Union Member States, with a special focus on tendering-like systems. [cited 2012 May 22]. Available from: whocc.goeg.at

29. Kanavos P. Tender systems for outpatient pharmaceuticals in the European Union: Evidence from the Netherlands, Germany and Belgium. EMINet, 2009.

30. Puig-Junoy J. Impact of European pharmaceutical price regulation on generic price competition: a review. Pharmacoeconomics. 2010 Aug 1;28(8):649-63.

31. Kullmann D, Palnoch D. PHIS Pharma Profile UK. London: PHIS; 2010 (unpublished).

32. Godman B, Burkhard T, Bucsics A, et al. Impact of recent reforms in Austria on utilization and expenditure of PPIs and lipid lowering drugs; implications for the future. Expert Rev Pharmacoecon Outcomes Res. 2009;9(5):475-84.

33. Wettermark B, Godman B, Andersson K, Gustafsson LL, Haycox A, Bertele V. Recent national and regional drug reforms in Sweden. Implications for pharmaceutical companies in Europe. Pharmacoeconomics. 2008;26:537-50.

34. Moïse $\mathrm{P}$, Docteur E. Pharmaceutical pricing and reimbursement policies in Sweden. OECD Health Working Papers. No. 28. OECD. Paris, 2007.

35. Brekke KR, Holmås TH, Straume OR. Are pharmaceuticals still inexpensive in Norway? A comparison of prescription drug prices in ten European countries. Oslo, R08/10

36. Håkonsen H, Horn AM, Toverud EL. Price control as a strategy for pharmaceutical cost containment - what has been achieved in Norway in the period 1994-2004? Health Policy. 2009;90(2-3):277-85.

37. Andersson KA, Petzold MG, Allebeck P, Carlsten A. Influence of mandatory generic substitution on pharmaceutical sales patterns: a national study over five years. BMC Health Serv Res. 2008 Feb 29;8:50.

38. Andersson K, Bergström G, Petzold MG, Carlsten A. Impact of a generic substitution reform on patients' and society's expenditure for pharmaceuticals. Health Policy. 2007;81(2-3):376-84.

39. Simoens S, Coster S. Sustaining generic medicines markets in Europe. Leuven: Research Centre for Pharmaceutical Care and Pharmaco-economics. Leuven University; 2006. Commissioned by European Generics medicines Association.

40. Gouya G. Reichardt B. Partial reimbursement of prescription charges for generic drugs reduces costs of both health insurances and patients. Wiener Klin Wochenschr. 2008;120:89-95.

41. Aaserud M, Dahlgren AT, Kösters JP, Oxman AD, Ramsay C, Sturm H. Pharmaceutical policies: effects of reference pricing, other pricing, and purchasing policies. Oslo, Issue 2, 2006.

42. Simoens S, De Coster S. Sustaining generic medicines markets in Europe. Journal of Generic Medicines. 2006;3:257-68.

43. Simoens S. Developing competitive and sustainable Polish generic medicines market. Croat Med J. 2009;50:440-8.

44. Teixeira I, Agostinho I. PPRI Pharma Profile Portugal. Lisbon: PPRI; 2008 [cited 2012 May 22]. Available from: ppri.goeg.at

45. Vogler S, Leopold C. Access to essential medicines in Portugal. Vienna: ÖBIG Forschungs-und Planungsgesellschaft mbH, 2009. 